delegates. He was ably assisted throughout by Count Albert Apponyi, the Hungarian Minister of Education, who made several important and statesmanlike speeches showing that he was in touch and in full sympathy with the work of the medical profession throughout the world.

The work of the congress was divided into official, sectional, and general. The official work was of unusual importance. It was decided that in future a meeting should be held once in four years instead of once in three years, as has been the case hitherto; that a permanent committee should be formed, with a president, a paid secretary, and a fixed office. Dr. F. W. Pavy, F.R.S., the president of the National Committee for Great Britain and Ireland, was nominated president, and it was determined that the oftice of the paid secretary should be at The Hague. By these means it is hoped that there will be a continuity of policy in the affairs of the congress which has hitherto been impossible, because there has been no permanent board to which difficulties and questions of policy could be referred.

The work of the sections did not prove of much interest, although many members attended and the papers were exceptionally numerous. The subjects chosen for discussion, like appendicitis, malignant disease of the larynx, the tuberculin treatment of tuberculosis, and uterine myomata, did not lend themselves to the expression of very novel views, and if the speakers who took part in them were not very inspiring, they were not belligerent, and the congress was spared the painful scenes which have occasionally turned the arena into a veritable battlefield.

Puerperal infection was selected appropriately as a subject of discussion. It was a tardy tribute to the memory of Semmelweis, the pioneer of modern obstetric prophylaxis, who died broken-hearted in the town where he had spent the best years of his life in declaiming against the fearful mortality of childhood and showing some of the means by which it might be avoided. He remained a voice crying in the wilderness until the end, but the statue erected by international effort, and placed in the gardens of the Ergebet-teren, was visited by every member of the congress, and was duly decorated with tributes from every nation.

The general addresses were excellent, and drew very large audiences, who listened most attentively. Prof. Holländer showed by means of lantern-slides some of the diseases and mutilations depicted in the records of the Incas and Huacos. Dr. Bashford, director of the Imperial Cancer Research in London, explained by similar means the present state of the cancer question, whilst Prof. Loeb, of Berkeley, made a remarkable communication upon artificial parthenogenesis.

The net outcome of the congress was the hold which the doctrine of immunity has gained upon the whole of the scientific side of the medical profession. Evidence of its importance was forthcoming from every side. There was a general discussion upon the subject. Dr. Bashford laid much stress upon it in his general address, and it formed an important factor in the work done by Prof. Loeb. It is evident that a great future lies before those who are working at the subject. At the present time there is much confusion and overlapping, a jargon of confusing terms masks the principles, but it is clear that before long the whole theory will be simplified and a most important agent will be added to the practice of medicine.

$$
\text { NO. 2082, VOL. 8I] }
$$

\section{THE INTERNATIONAL SEISMOLOGICAL} ASSOCIATION.

$\mathrm{THE}$ third meeting of the permanent committee of the International Association of Seismology was held at Zermatt on Monday, August 30, and the three succeeding days. Out of twenty-two States which now belong to the association, seventeen were represented. In his presidential address, Prof. Schuster directed attention to the importance of determining the movement of the soil in a seismic disturbance, and laid stress on the conditions which seismographs must satisfy, in order that the components of the displacements should be capable of being deduced from the records obtained.

A number of committees, which had been appointed at the previous meeting, now presented their reports. Perhaps the most important of these referred to the microseismic oscillations, which have lately attracted attention in many places. Two kinds of oscillations are to be distinguished, one having a period varying between four and nine seconds, and the other a period of about half a minute. The short-period microseism is often observed simultaneously over large portions of the earth's surface; its most interesting feature, which was independently discovered by Prince Galitzin in Pulkowa, by Hecker in Potsdam, and by Omori in Japan, is that there is a direct relationship between the amplitude of the oscillation and the period, the larger amplitude corresponding to the longer period. Dr. Klotz, the representative of Canada, has also investigated the subject, and found that whenever a centre of low barometric pressure, after traversing the continent, reaches the ocean, these microseismic waves of short period appear. Though we cannot at present give a quite satisfactory explanation of these waves, Prof. Wiechert's suggestion that they are caused by the impact of ocean waves on land areas deserves further investigation. For this purpose the committee intends to set up, probably on the west coast of Ireland, an instrument capable of registering the number and height of the waves. The microseismic disturbances, which have a period of about half a minute, have been found to depend on the intensity of local winds. They seem due to a wave-motion set up on land in a similar manner to that in which waves are set going on the ocean.

Probably the most important communication made to the meeting was that in which Prince Galatzin showed that it is possible to determine the azimuth of the seat of an earthquake by combining the indications of two seismographs, set up so as to give displacements in two directions at right angles to each other. The coincidence of the azimuth determined in this way for a number of earthquakes with that known independently was quite remarkable, the difference in many cases being less than a degree. As the distance of the earthquake can be determined from the interva! elapsing between the arrivals of the forerunners and surface waves, Prof. Galitzin's investigations show that it is possible to fix the locality of an earthquake by observations at one distant station only; but such a result could only have been achieved by means of a perfection of instrumental appliances consequent on a complete mastery of the problems involved. Mr. H. F. Reid, of Baltimore, unable, unfortunately, to be present himself, sent a communication, in which he summarised his experiences gained by a study of the San Francisco earthquake. After directing attention to various instrumental matters, notably the absence of damping in many of the American instruments, which rendered the investigation difficult, he suggests the theory of a slow secular displacement as a pre- 
liminary condition leading to a seismic catastrophe, and shows how, if this theory be true, a certain class of earthquakes might be predicted.

Prof. Omori communicated a report on the Messina earthquake, in addition to his report on microseismic waves.

Communications were also made, among others, by Prof. Palazzo, of Rome; M. Angot, of Paris; M. Rosenthal, of Tiflis; M. Choffat, of Lisbon; while Prof. Hecker, of Potsdam, gave an account of his more recent results of tidal displacements in the earth. The meeting concluded with a lecture by Prof. Heim, in which an historical summary of the subject was given from the geologist's point of view.

At previous meetings the desire had been expressed that a complete bibliography of the subject should be published annually; a committee was appointed which reported in tavour of coming to an arrangement with the International Catalcgue of the Royal Society, all papers on seismology in that catalogue to be joined together in one volume, instead of, or perhaps in addition to, their being classified, as at present, partly under geology, partly under physics, and partly under applied mathematics. There is good ground for believing that such an arrangement could be made, and the meeting adopted the committee's report.

A report on the arrangements for an annual catalogue of earthquakes was presented by Prof. Forel, of Morges. The method to be adopted in such a catalogue, in order to make it most generally useful, gave rise to a good deal of difference of opinion; but after discussion in committee a compromise between different views was effected. Prof. Forel having completed his tenure of office as vice-president, M. Hipites, of Bucarest, was elected to be his successor.

The Federal Council of the Swiss Republic had entrusted the arrangements for the meeting to the Schweizerische Naturforschende Gesellschaft, and, with the assistance of Mr. Seiler, the delegates and their families were cared for in a most excellent manner. At the conclusion of the meeting satisfaction was expressed both at the success of the scientific results, and at the hospitable reception accorded to the members present.

\section{BRONZE-AGE INTERMENTS IN SWITZER- LAND.}

UNDER the title of "Le Cimetière du Boiron de Morges," M. F. A. Forel has issued a report on some remarkable prehistoric interments in Switzerland, and though it occasionally lacks the lucidity of arrangement and grace of style which characterise French work of this kind, it will still be found full of interest.

These interments are attributed to the Bronze age, or, as the author terms it, "le bel-âge du bronze des Palafitteurs." The graves are flat, without mounds or stone pedestals, the latter, he thinks, having been probably replaced by wooden posts which have now decayed. They lie in no definite order or in lines one behind another; nor is there any rule of orientation in the graves themselves. It is remarkable that earth burial and cremation are found side by side; in fact, the two methods of disposal of the dead seem to be contemporary, if the evidence of identity in the style of vases and bronzes deposited with the corpse be accepted as conclusive. It may be noted that $\mathbf{M}$. Forel treats as cases of inhumation those in which the teeth are found intact; those of incineration when the roots of the teeth alone survive. There is nothing in the shape of a regular cist, only a slab laid in a horizontal position over the head and upper part of the body. NO. 2082, VOL. $8 \mathrm{I}]$
The slab graves of this class contained funeral plates and dishes, or piles of urns and bowls, three or four in number, laid one above another. Only one tomb which held a cremated corpse contained a cinerary urn; in the others the bones lay in the mass of charcoal and other remains of the cremation. In such interments only a single corpse was discovered; hence it is supposed that the custom of sacrificing slaves or animals in the belief that their spirits would accompany the dead to the other world did not prevail. There are occasional remains of some kind of coffin; and in the cremation graves the jars probably contained offerings of food to the dead, meat in some cases forming part of such deposits. It is thus obvious that the people who used this cemetery believed in the survival of the spirit after death. M. Forel seems to imagine that this custom of providing food for the dead implies the existence of a sacerdotal class; but this is not confirmed by the analogy of the customs of modern savages, among whom the head of the household or some tribal elder performs the death rites.

The paper is accompanied by photographs of the graves and their contents, and is, on the whole, a useful contribution to our knowledge of the Bronze Age on the continent of Europe.

\section{NOTES.}

We learn from the Pioneer Mail that the Government of India has issued a resolution concerning malaria in India. The Governor-General has had under consideration a proposal of the sanitary commissioner that a permanent organisation should be formed to inquire systematically into the problems connected with malaria. The number of deaths ascribed to fever throughout India approximates to four and a half millions, representing a mean death-rate of nearly twenty per thousand, and though this total is greatly in excess of the actual figure, owing to the practice of ascribing to "fever" deaths which are in reality due to other causes, yet it has been estimated that the actual death-rate from malarial fever is about five per thousand. The Governor-General has decided to convene a conference to examine the whole question, and to draw up a plan of campaign for the consideration of the Government of India and of the local governments. The conference will assemble at Simla on October II, and it is expected that it will last about a week. The following is a rough outline of the subjects to be discussed:-(r) the distribution of malaria in India as a whole and in various provinces, with special reference to the sickness and mortality to which it gives rise; (2) the measures of prevention which have been adopted in the different provinces-drainage, mosquito destruction, the distribution of quinine-and the measure of success which has attended each; (3) the improvement of schemes of prevention, including the question of the most suitable form of quinine and the agency by which it can most effectively be distributed.

ThE International Aëronautical Congress at Nancy opened on Saturday last, and will conclude to-day. The programme included papers on dirigible airships, on light motors for airships and aëroplanes, on the history of aëroplanes, on cartography, on photographic topography from balloons, on the properties and uses of hydrogen, and on the theory and practice of aërodynamics.

AT the Brescia aviation meeting a record in altitude flight was made on Monday last by $M$. Rougier, who ascended to a height of $198.5^{\circ}$ metres $(645$ feet), as com- 